\title{
Sources and Characteristics of Liquid Process Wastes From Arctic Offshore Hydrocarbon Exploration
}

\author{
S.E. HRUDEY, P. ENG.
}

\begin{abstract}
Increased interest in offshore hydrocarbon exploration in Arctic waters raises concern regarding liquid waste management from drilling operations. The typical sources of process liquid waste from exploratory drilling operations is described and data on the quantity and quality of liquid waste discharges is provided from monitoring at two offshore sites. The chemical and toxicological characteristics of the waste fluids indicate that a potential exists for water pollution in specific circumstances. However, close process control to reduce the quantities of waste fluid generated and judicious selection of drilling mud additives should prevent the occurrence of significant water pollution problems from waste fluid disposal at exploratory Arctic offshore drilling operations.
\end{abstract}

RESUME. Avec l'accroissement d'intérèt dans l'exploration petrolière marine dans les eaux arctiques, a grandi celui du traitement des pertes liquides en provenance des opérations de forage. On décrit ici les sources typiques des pertes liquides à traiter venant des opérations de forage et on fournit les données sur les quantités et qualités des décharges de liquide perdu, provenant d'enregistrements de deux emplacements en mer. Les caracteristiques chimiques et toxicologiques des fluides perdus indiquent qu'une pollution de l'eau est possible dans des circonstances speciales. Cependant, un traitement contrôlé de tràs près devrait réduire les quantités produites de pertes liquides et une judicieuse selection d'additifs aux boues de forage devrait empêcher d'avoir des problèmes importants de pollution de l'eau en provenance des pertes de fluides pendant les operations de forage en mer arctique.

Traduit par Alain de Vendegies, Aquitaine Company of Canada Ltd.

\section{INTRODUCTION}

There has been considerable oil and gas exploration activity in the Canadian Arctic in recent years despite the generally difficult environmental conditions of this region. Until 1973, drilling activity was restricted to conventional land based locations. However, during the winter of 1973-74, two wells were drilled from man-made islands in the shallow regions of Mackenzie Bay. Since these pioneering operations, there has been increased drilling activity in Arctic marine waters.

Although publicized environmental concerns regarding exploratory drilling operations have been understandably focussed on the probability and consequences of an uncontrolled oil blowout, investigations have been initiated (Bryant $e$ t al., 1974) to evaluate the environmental significance of routine waste disposal from exploratory drilling operations.

Prior to 1973, published information concerning the sources and characteristics of liquid wastes from drilling operations was sparse. Daugherty

Associate Professor, Department of Civil Engineering, University of Alberta, Edmonton, Alberta T6G 2G7 
(1951) conducted some experiments to determine the toxicity to marine invertebrates and fish of a few basic chemicals used in drilling operations. Bentonite clay was found to be relatively non-toxic, sodium acid pyrophosphate was lethal to test animals in concentrations ranging from 500 to $7500 \mathrm{mg} / \mathrm{l}$ and caustic soda, oil well cement and lime were fatal to many test animals at concentrations ranging from 70 to $450 \mathrm{mg} / \mathrm{l}$. Carbrera (1968) reported that diluted drilling fluids exceeding $200 \mathrm{mg} / l$ reduced the survival of oysters. Collins (1971) speculated that drilling wastes could potentially cause water pollution but detailed studies on their characteristics were non-existent at that time. Logan, et al. (1973) found that out of 27 common chemicals used in drilling operations, 13 were acutely lethal (rapid death of test organisms, generally in less than 96 hours) to rainbow trout at concentrations below 1000 $\mathrm{mg} / \mathrm{l}$. Falk and Lawrence (1973) tested drilling fluid samples on rainbow trout and various indigenous species finding $96 \mathrm{hr}$ LC50 values (concentrations lethal to $50 \%$ of the test species provided with up to 96 hours exposure) ranging from $3.6 \%$ to $12.0 \%$.

Since many drilling operations were located in low lying regions of the Mackenzie Delta which are subjected to spring flooding and because of the imminent activities in offshore areas, a program of studies to investigate the characteristics of drilling wastes was initiated in March 1973. The program was sponsored by Environment Canada, Indian and Northern Affairs and the Arctic Petroleum Operators' Association. The findings of these studies (Bryant, 1976) provide the majority of the information currently available on Arctic drilling waste production and characteristics.

Since the hydrocarbon potential of offshore areas in the Canadian Arctic appears to be significant, offshore exploratory drilling activity is likely to increase in the future, barring a major change in regulatory policy by the federal government. Such offshore drilling operations are faced with more difficult waste management problems than land based operations. The latter are normally able to contain drilling wastes within a sump which, with care, can be reclaimed by freezing and backfilling to encourage incorporation of the frozen waste fluids into the permafrost. Studies by Hrudey, et al. (1976) indicate that this approach can limit surface and groundwater pollution to a very localized area around the sump. Containment and landbased disposal of drilling waste is not normally feasible for offshore locations because of the logistics of storage and transportation, particularly during winter drilling. Winter drilling has only been feasible from artificial island locations but technology development is being undertaken for year round activity from drilling vessels. Because of the potential problems associated with Arctic offshore drilling a monitoring study was undertaken to evaluate the sources and characteristics of the wastewaters generated (Hrudey and McMullen, 1976).

Effective waste management for offshore drilling operations requires adequate knowledge of the sources, quantities and characteristics of the wastes produced. 


\section{DRILLING WASTE PRODUCTION}

\section{Water Use and Waste Sources}

As with the majority of industrial processes, drilling for hydrocarbons requires the use of water for various purposes. Unfortunately, many of these uses require the mixing of water with materials which degrade its character prior to being returned to the environment. The main water uses in a drilling operation, exclusive of the domestic requirements of the work camp, are steam generation, rig washing and mud formulation.

Steam generation is required for various energy requirements in the rig operation. Fortunately, steam generation does not generally produce a significant amount of wastewater. A large proportion of water used for steam generation will be lost as water vapour and thus water intake records for a rig operation will not necessarily accurately reflect the waste fluid discharge. Unless toxic corrosion inhibitors or biocides are used in boiler water treatment, condensed waste steam should not account for a significant wastewater disposal problem.

Rig wash waters are generated by the need for keeping the rig working areas clean for occupational safety reasons. Patches of oils, grease or drilling mud, can make footing unreliable and pose hazards to rig personnel. The machinery used on a drilling rig require the use of significant amounts of lubricating oils and greases. Poorly maintained seals will constantly leak these lubricants, creating the need for frequent cleanup. The removal of the oils and greases necessitates the use of detergents to emulsify these hydrophobic materials in the wash-water. Unfortunately, detergent use increases the difficulty of controlling hydrocarbon discharges, since emulsified oils are not amenable to conventional gravity separation. In addition, the detergents themselves exhibit significant toxicity to fish (Bryant and Hrudey, 1976), likely because of their surfactant properties.

The most important water use from a waste production viewpoint, is that required for drilling mud formulation. Drilling muds are necessary in modern rotary drilling applications to lubricate the drill bit and stem, carry drilled formation solids away from the drilling interface and up to the surface, seal the drilled hole against excessive inward or outward fluid movements and to provide increased static pressure in the drilled hole to counteract the high pressures under which hydrocarbons may exist in underground formations.

Drilling mud is pumped down the center of the hollow drill string to which the drill bit is attached. At the bottom, the flow of mud out of the drill bit contributes to the cutting action of the bit and then picks up the drill cuttings to carry them up to the surface in the annulus between the drill string and the casing (or the wall of the drilled hole, before casing is set). Because large quantities of mud chemicals are required and transportation costs of these materials to the Arctic can make them rather expensive, there is an economic incentive to recover and recycle mud to a high degree. However, before mud can be recycled, the drill cuttings which interfere with the desired properties of the mud, must be removed. This is generally achieved in a sequence of 
physical treatment processes. These are generally a shale shaker (primary screen), a desander and a desilter.

The primary screens consist of a vibrating sloped screen designed to retain coarse materials such as would be produced from shale cuttings. Finer mud particles are allowed to pass through. This process gives rise to a waste stream of removed solids, which is termed the shaker overflow.

The desander is a centrifugal cleaner or cyclone in which mud tangentially enters a conical section. The more dense solids migrate to the outer walls and pass out the bottom of the device while the less dense solids rise up the center core of the cone and go out as the overflow. Thus, the desander underflow is a reject stream of sand and grit removed from the mud. Inevitably, the separation in these devices is not sharp and a significant amount of mud solids may be discharged into the underflow.

The desilter is similar to the desander but is designed to recover fine particles from the recycled mud stream. The desilter will tend to have an even larger carryover of mud solids because of the difficulty of sharply separating silt particles from mud solids.

Other recovery systems such as secondary screens and/or centrifuges may be used to recover mud weighting materials, commonly barytes $\left(\mathrm{BaSO}_{4}\right)$. With both the centrifuge and secondary screens, the weighting material is recovered by means of its density differential from the finer mud solids.

The drilling operations monitored in this study deployed primary screens, desanders, desilters, secondary screens and a centrifuge.

Because the strata encountered change with depth, drilling requirements change. This is particularly true in the Arctic where permafrost must be dealt with during the first thousand metres of drilling. At greater depths, the need for balancing formation pressure with mud weight becomes important. Thus, the formulation of drilling muds may vary considerably from the surface hole to the bottom hole.

Mud technology has become very complicated in response to the wide range of drilling conditions which may be encountered. Several hundred drilling mud components and additives are currently marketed under a variety of trade names (Wright, 1977). Many individual components are sold under several different trade names by the different mud chemical suppliers. In general, as Arctic drilling operators have gained increased experience with the drilling conditions likely to be encountered, they have tended to simplify their mud recipes to avoid unnecessary, exotic, additives. Such simplification can result in considerable savings by allowing common inventories of certain "essential" mud additives. One basic, simplified mud program, as used in the drilling operations monitored in this study, consisted of a mixture of bentonite, organic polymer, potash and caustic soda while drilling through the permafrost zone (up to $900 \mathrm{~m}$ depth). The bentonite and polymer provide the mud with the necessary viscosity to perform its various functions, particularly the transport of drill cuttings. The potash functions as a flocculent and acts to reduce shale swelling which may cause the drill stem to become stuck in the hole. The use of potash has been found necessary for drilling through 
permafrost. Caustic soda acts to maintain high $\mathrm{pH}$; control calcium which can degrade the mud properties; and maintain some bactericidal action to reduce microbial degradation of organic mud components. Once through the upper section of the hole, potash is generally not required to any significant degree while barytes are added to increase the mud density. As drilling depth increases, the baryte concentration must increase to provide sufficient mud density to prevent the occurrence of a blowout. The increasing concentration of barytes causes mud viscosity to increase to undesirable levels. In order to counter this effect the organic polymer will be gradually replaced by a thinning agent such as lignosulphonate. The latter is derived from the treatment of wood lignin with bisulphite, as performed in the sulphite wood pulping process.

Various other mud additives may be used in small quantities, but the foregoing represented the major mud components used in the drilling sites monitored in this study.

Drilling mud becomes a waste material at various times during a drilling operation. When drilling mud composition must be changed, as different conditions are encountered, it is usually necessary to discharge batches of the mud with the unwanted properties in order that fresh mud may be made. An example would be the wasting of the $\mathrm{KCl}$ mud after completion of the surface hole. Other common circumstances requiring the wasting of mud are: cement contamination of mud when casing is being set; inadequate removal of drilled fines by the mud treatment system and final abandonment of the well. Thus, the characteristics of drilling mud components and whole fluids are important because of the ultimate necessity to dispose of waste mud from the drilling operation.

\section{Quantities of Waste Production}

The assessment and control of water pollution from exploratory drilling operations is hampered by the lack of accurate information on quantities of waste production and wastewater volumes. Although many drilling operations may meter their water intake, the routine measurement of waste volumes has been limited, if not non-existent. This situation is due, in part, to the circumstances surrounding land based drilling operations. These operations normally construct a sump to receive all waste fluids except for separable hydrocarbon wastes. Since, the sump wastes should remain contained, under fortunate conditions, there has been very little stimulus to encourage the measurement of waste fluid volumes. Although total waste volumes for a drilling operation could be estimated by estimating the volume of fluid contained in the sump (Bryant and Hrudey, 1976) this volume is subject to unknown contributions from precipitation, surface runoff and permafrost melt. Furthermore, the total volume does not indicate the contribution of the various individual processes to the overall waste fluid volume.

Thus, a concerted effort was made in this monitoring program to estimate the quantities of waste fluid contributed by various sources. The major liquid wastes produced at the operations monitored in this study were washwater, 

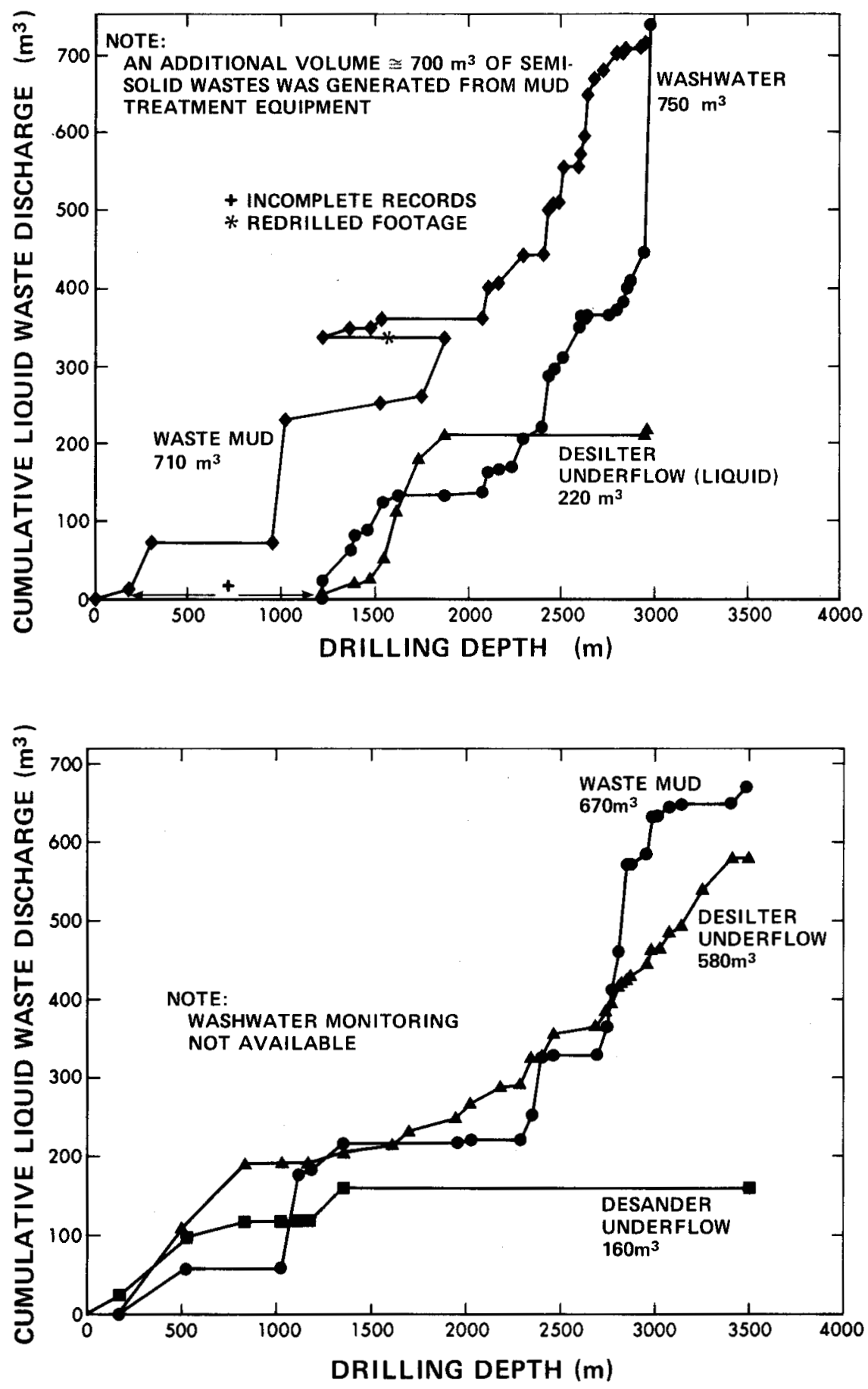
waste mud, desilter underflow, desander underflow and shaker overflow. The discharge record of these waste materials versus depth are plotted in Figures 1 and 2 . The notable features of these plots is the consistent production of reject waste from the mud treatment system (shaker overflow, desilter underflow, desander underflow) in the first half of the hole, with little contribution from these sources at greater depths. The major exception to this observation is the consistent production of desilter underflow at Site 2 . The general decrease in waste mud generated from the formation is expected at greater depths because the diameter of the hole is intentionally decreased in stages as drilling progresses. Thus, less formation material is cut per metre of hole, at the greater depths. The waste mud discharges tend to jump in steps as batch discharges of mud were necessitated by changing drilling conditions.

When considering the patterns of waste production for drilling operations, generalizations are risky because the actual pattern is very dependent upon the geology of the formation. For instance, where high formation fluid pressures are encountered, weighted mud must be used earlier than normal in the drilling operation. This leads to a greater proportional discharge of waste mud as close control on mud composition is necessary to maintain the required mud weight in concert with the other necessary physical properties. As well, cuttings from a sandstone formation (as encountered at Site 2) are more readily separated by the mud treatment processes than cuttings from mudstone or shale formations (as encountered at Site 1). Thus, although the figures estimated for these two operations are informative, their unqualified application to other drilling operations is not recommended. However, one obvious conclusion to be drawn from this monitoring program is that when close control is maintained on waste discharges, the total volumes can be reduced considerably from less tightly controlled operations. This is demonstrated by considering the finding of Bryant and Hrudey (1976), based on estimated waste discharges from 21 exploratory wells in the Arctic, that a typical $3000 \mathrm{~m}$ well generated about $4000 \mathrm{~m}^{3}$ of waste fluid. These sites were all land based and the only significant constraints on waste fluid discharge were the size of the sump and desire to avoid unnecessary wastage of mud chemicals. In contrast, the two offshore wells, subject to tighter operational control, each apparently generated total waste volumes of less than $2500 \mathrm{~m}^{3}$. The accuracy of the estimate for Site 2 is hampered by the lack of a monitoring record for washwater discharge.

Another perspective for the quantities of waste discharge may be gained by evaluating the mud inventory for chemicals used in mud formulation versus the estimated chemical content of mud lost to the formation or left in the hole upon abandonment. The difference would be discharged in waste mud. Such estimates, prepared by the operator, are provided in Table 1. These estimates indicate that the majority of mud chemicals used will ultimately be discharged as waste mud, unless very unfavourable loss of mud circulation to the formation occurs. However, the higher the degree of mud rehabilitation and recycle, the lower the requirements for final mud makeup and ultimate wastage of mud components. 
TABLE 1. Mud Chemicals Used and Estimated Discharged

\begin{tabular}{|c|c|c|c|c|}
\hline \multirow[b]{2}{*}{ Mud Chemical } & \multicolumn{2}{|c|}{ Site 1} & \multicolumn{2}{|c|}{ Site 2} \\
\hline & $\begin{array}{c}\text { Used } \\
\text { kg }\end{array}$ & $\begin{array}{c}\text { Estimated } \\
\text { Discharge } \\
\mathrm{kg}\end{array}$ & $\begin{array}{c}\text { Used } \\
\mathrm{kg}\end{array}$ & $\begin{array}{c}\text { Estimated } \\
\text { Discharge } \\
\text { kg }\end{array}$ \\
\hline barytes & 550,000 & 290,000 & 68,000 & 47,000 \\
\hline bentonite & 63,000 & 33,000 & 64,000 & 49,000 \\
\hline caustic soda & 5,000 & 4,500 & 4,600 & 4,500 \\
\hline organic polymer & 2,200 & 1,700 & 1,200 & 1,200 \\
\hline potash & 19,000 & 10,000 & 23,000 & 23,000 \\
\hline lignosulphonate & 11,000 & 2,500 & 3,100 & 1,800 \\
\hline sodium bicarbonate & 2,900 & 2,900 & 730 & 590 \\
\hline sodium acid pyrophosphate & 140 & 140 & 730 & 730 \\
\hline $\begin{array}{l}\text { calcium chloride } \\
\text { (1) }\end{array}$ & $-\infty$ & - & 1,700 & 1,700 \\
\hline
\end{tabular}

\section{DRILLING WASTE CHARACTERISTICS}

\section{Sampling and Analysis}

The properties of drilling wastes derive from the properties of drilling muds, namely viscosity, high solids content and a gel emulsion. These characteristics combine to produce a waste which is very difficult to sample and analyze with confidence.

Evaluation of sampling procedures for drilling sump fluids by Bryant and Hrudey (1976) indicated that very wide variations in results could arise unless very rigorous sampling procedures were followed. Using the particular procedure developed for locating arbitrary sample points within a sump and obtaining depth proportioned composite samples, percentage errors between replicate samples varied from 0 to $56 \%$ for a variety of parameters. However, using the same technique but choosing sampling sites intentionally randomized from the previously specified sites, percentage errors ranged up to $290 \%$. These findings confirmed expectations that the high particulate fraction of drilling wastes contributes a large degree of heterogeneity to the wastes.

Although the problems in sampling these wastes were considerable, these problems are at least matched by the problems encountered in analyzing them. Studies by Strosher, et al. (1974) indicated the need for care in subsampling to obtain aliquots for analysis because of the major influence of the particulate fraction on individual parameters. In an associated study by Strosher and Bogner (1975) the analysis of drilling wastes for oil and grease by "Standard Methods" (APHA, 1971) was found to be very difficult because of interference by the particulate fraction and the propensity of drilling mud solids toward the formation of very stable emulsions.

For this study, sampling was facilitated by the presence of reserve tanks on the rigs in which waste fluids were diluted with seawater prior to discharge. These tanks were equipped with paddle and jet mixers which allowed the collection of relatively more homogenous samples than has been possible in other studies on drilling waste characteristics (Bryant and Hrudey, 1976). 
TABLE 2. Chemical Characteristics of Waste Drilling Fluids

\begin{tabular}{|c|c|c|c|c|c|c|c|c|c|c|c|}
\hline \multirow[b]{2}{*}{ Sample Type } & \multirow[b]{2}{*}{$\begin{array}{c}\text { Number } \\
\text { of } \\
\text { Samples }\end{array}$} & & \multicolumn{9}{|c|}{ Parameter Concentration Ranges } \\
\hline & & & $\begin{array}{c}\text { Specific } \\
\text { Conductance }\end{array}$ & $\begin{array}{c}\text { pH } \\
\text { Units }\end{array}$ & $\begin{array}{c}\text { Potassium } \\
\mathrm{mg} / \mathrm{l}\end{array}$ & $\begin{array}{c}\text { Total } \\
\text { Chromium } \\
\text { mg } / l\end{array}$ & $\begin{array}{c}\text { Soluble } \\
\text { Chromium } \\
\text { mg/l }\end{array}$ & $\begin{array}{c}\text { Total* } \\
\text { Organic } \\
\text { Carbon } \\
\text { mg } / l \\
\end{array}$ & $\begin{array}{c}\text { Total } \\
\text { Kjeldahl } \\
\text { Nitrogen } \\
\text { mg/l } \\
\end{array}$ & $\begin{array}{c}\text { Petroleum } \\
\text { Ether } \\
\text { Extractibles } \\
\mathrm{mg} / l \\
\end{array}$ & $\begin{array}{c}\text { Chemical } \\
\text { Oxygen } \\
\text { Demand } \\
\text { mg/l }\end{array}$ \\
\hline $\begin{array}{l}\text { KC1 Mud } \\
\text { (Surface } \\
\text { Hole) }\end{array}$ & 5 & $\begin{array}{l}\text { Range } \\
\text { Median }\end{array}$ & $\begin{array}{c}3700-39,000 \\
29,000\end{array}$ & $\begin{array}{c}7.9-11.6 \\
8.7\end{array}$ & $\begin{array}{c}6500-8800 \\
7800\end{array}$ & $\begin{array}{c}1.1-13.0 \\
3.8\end{array}$ & $\begin{array}{c}0.1-0.4 \\
0.3\end{array}$ & $\begin{array}{c}2100-2600 \\
2300\end{array}$ & $\begin{array}{c}6-4400 \\
120\end{array}$ & $\begin{array}{c}71-460 \\
380\end{array}$ & $\begin{array}{c}4400-10,000 \\
9600\end{array}$ \\
\hline $\begin{array}{l}\text { Freshwater } \\
\quad \text { Mud } \\
\text { (Intermediate } \\
\text { Hole) }\end{array}$ & 5 & $\begin{array}{l}\text { Range } \\
\text { Median }\end{array}$ & $\begin{array}{c}18,000-21,000 \\
20,000\end{array}$ & $\begin{array}{c}8.0-9.4 \\
9.1\end{array}$ & $\begin{array}{c}340-520 \\
-\end{array}$ & $\begin{array}{c}6.5-18.0 \\
9.5\end{array}$ & $\begin{array}{c}0.1-0.2 \\
0.1 \\
\end{array}$ & $\begin{array}{c}1400-1500 \\
-\end{array}$ & $\begin{array}{c}32-1700 \\
46\end{array}$ & $\begin{array}{c}21-550 \\
430\end{array}$ & $\begin{array}{c}3900-15,000 \\
6100\end{array}$ \\
\hline $\begin{array}{l}\text { Weighted } \\
\text { Mud } \\
\text { (Bottom } \\
\text { Hole) }\end{array}$ & 5 & $\begin{array}{l}\text { Range } \\
\text { Median }\end{array}$ & $\begin{array}{c}4400-29,000 \\
8100\end{array}$ & $\begin{array}{c}9.1-9.8 \\
9.2\end{array}$ & $\begin{array}{c}80-100 \\
-\end{array}$ & $\begin{array}{c}7.8-910 \\
55\end{array}$ & $\begin{array}{c}2.4-560 \\
6.6\end{array}$ & $\begin{array}{c}3300-19,000 \\
4900\end{array}$ & $\begin{array}{c}31-3700 \\
1200\end{array}$ & $\begin{array}{c}100-1200 \\
\sim 680\end{array}$ & $\begin{array}{c}9100-64,000 \\
17,000\end{array}$ \\
\hline $\begin{array}{l}\text { Desilter } \\
\text { Underflow } \\
\text { (Intermediate } \\
\text { Hole) }\end{array}$ & 1 & - & 20,000 & 8.8 & 230 & 24 & 0.3 & 2200 & 2900 & 150 & 13,000 \\
\hline Washwater & 1 & - & 1600 & 8.6 & - & 4.7 & 1.8 & 180 & 10 & 2 & 520 \\
\hline
\end{tabular}

- Based on 2 or 3 samples from Site 1 only, for parameters indicated.

- Median estimated by an average of two intermediate values. Only four data points available since analysis of one sample failed 
TABLE 3. Estimated Total Components Discharged in Waste Fluids

\begin{tabular}{|c|c|c|c|c|c|c|c|}
\hline SITE 1 & $\begin{array}{c}\text { Volume } \\
\mathbf{m}^{\mathbf{3}}\end{array}$ & $\begin{array}{c}\text { Potassium } \\
\mathbf{k g}\end{array}$ & $\begin{array}{c}\text { Total } \\
\text { Chromium } \\
\text { kg }\end{array}$ & $\begin{array}{c}\text { Total } \\
\text { Organic Carbon } \\
\mathbf{k g} \\
\end{array}$ & $\begin{array}{c}\text { Total } \\
\text { Kjeldahl } \\
\text { Nitrogen } \\
\text { kg } \\
\end{array}$ & $\begin{array}{c}\text { Petroleum } \\
\text { Ether } \\
\text { Extractibles } \\
\text { kg } \\
\end{array}$ & $\begin{array}{c}\text { Chemical } \\
\text { Oxygen } \\
\text { Demand } \\
\text { kg }\end{array}$ \\
\hline Waste Whole Mud & 700 & 1400 & 70 & 2600 & 1500 & 500 & 12,000 \\
\hline Destilter Underflow & 200 & 50 & 5 & 500 & 600 & 30 & 3,000 \\
\hline Washwater & 700 & - & - & 100 & - & - & - \\
\hline Total & 1600 & 1450 & 75 & 3200 & 2100 & 530 & 15,000 \\
\hline \multicolumn{8}{|l|}{ SITE 2} \\
\hline Waste Whole Mud & 700 & - & 30 & - & 50 & 400 & 8,200 \\
\hline Extrapolated Total ${ }^{*}$ & 1600 & - & 40 & - & 60 & 500 & 10,000 \\
\hline
\end{tabular}

*These figures were estimated based on the chemical characteristics of the waste fluids (other than waste mud) which were collected at Site 1. The Site 1 concentrations were applied to the volume discharge estimates for these wastes at Site 2 in order to estimate the total mass discharge from Site 2.

NOTE: Total volumes shown do not include semi-solid waste materials such as the shaker overflow, desander underflow and part of the desilter underflow. 


\section{Chemical Characteristics}

The major chemical characteristics of the wastes discharged from the drilling operations are summarized in Table 2. The most significant feature of this monitoring data is the striking variation in the values of the various parameters. This finding indicates that it is likely not possible to specify a "typical" composition for waste drilling fluids. The estimated total discharge of each parameter at each site is provided in Table 3. The significance of each parameter will be discussed in turn.

The specific conductance is a measure of the electrical conductivity of the sample and is therefore a measure of the presence of ionic species or the salinity. The surface hole mud exhibits an expected high salinity, largely due to the use of potash $(\mathrm{KC} 1)$ in mud formulation. However, the specific conductance remains high in the fresh water and weighted muds. This is due to the use of several additives which ionize in solution such as caustic soda $(\mathrm{NaOH})$, bicarbonate of soda $\left(\mathrm{NaHCO}_{3}\right)$ and sodium acid pyrophosphate $\left(\mathrm{Na}_{2} \mathrm{H}_{2} \mathrm{P}_{2} \mathrm{P}_{7}\right)$. As well, the salinity of the intake waters, which fluctuated considerably at MacKenzie Bay drilling locations, would contribute conductance to the intake waters. Salinity, as represented by specific conductance, poses an environmental concern as a wastewater parameter, only where discharge to fresh receiving waters is proposed.

The $\mathrm{pH}$ is a measure of hydrogen ion activity and as such gives an indication of the acidic or basic character of a wastewater. The surface mud, with the exception of one sample does not differ markedly from well buffered freshwaters $(\mathrm{pH} \sim 8)$. Mud samples at lower depths indicate higher $\mathrm{pH}$, due to the increased use of caustic in mud formulation. The $\mathrm{pH}$ of wastes can be a contributor to toxicity as individual organisms usually have a relatively narrow $\mathrm{pH}$ tolerance range. A receiving water $\mathrm{pH}$ range of $6.5-8.5$ is generally regarded as acceptable for most aquatic organisms. The $\mathrm{pH}$ of the drilling wastes was generally not extreme and would tend to be neutralized by the buffering capacity of receiving waters. Problems due to $\mathrm{pH}$ of the waste mud would be limited to circumstances of low dilution and buffering capacity in the receiving water.

Potassium was clearly contributed to the mud samples by the addition of potash, as indicated by the sharp decline in potassium concentrations in the intermediate and bottom hole mud samples. Potassium is apparently the most toxic of the alkali metals and Land (1974) concluded, based on a review of the literature, that concentrations down to $100 \mathrm{mg} / \mathrm{l}$ could be harmful to the freshwater aquatic environment. The high values found for potassium indicate that some concern may be necessary for surface hole waste mud discharges to fresh or low salinity receiving waters. Where discharge occurs to saline waters, dilution of the contributed potassium to background levels would be much more rapid.

The chromium concentrations were measured as both the total (particulate and soluble) and soluble chromium. The chromium is largely contributed by the addition of lignosulphonate which is commercially prepared as a chromium salt. In some cases, chromium may also be present in corrosion 
inhibitors and bactericidal additives. However, for this monitoring data, the chromium is clearly contributed by the lignosulphonate, which is added in greater amounts as the mud weight is increased. The toxicity of chromium varies widely for different aquatic organisms and different ionic forms. However, a receiving water concentration of $<.05 \mathrm{mg} / \mathrm{l}$ is recommended for total chromium in order to protect a mixed population of aquatic organisms (N.A.S., 1973). The concentrations of chromium in drilling mud are generally in excess of this receiving water recommendation. Although dilution to the receiving water value would occur in most circumstances, chromium is a nondegradable pollutant and therefore can become harmful with long term, low level discharge. However, the treatment of waste drilling muds to specifically remove chromium is likely not feasible. The best prospect for reducing chromium discharge from drilling operations would be the elimination of chromium from the mud components used.

The total organic carbon (TOC) parameter measures the carbon content of the organic matter present in the waste samples, but is not specific as to the type of compound. The organic polymer used in surface hole mud and the lignosulphonate added at greater depths likely account for most of the organic carbon measured in mud samples. Some organic matter is likely also contributed by the drill cuttings. The significance of TOC is difficult to assess because of the complete range of toxicological characteristics exhibited by different organic compounds. However, the high organic content of drilling wastes suggests that drilling muds should be capable of supporting a large microbial population. This expectation has been confirmed by Bell (1974). The action of microorganisms on the organic fraction of drilling muds has led to the use of bactericides such as pentachlorophenol and formaldehyde in some drilling locations. The use of these toxic additives is extremely undesirable for drilling wastes intended for discharge.

The total kjeldahl nitrogen (TKN) parameter measures all nitrogen present in organic matter or as ammonia. Nitrogen ions such as nitrate and nitrite are not measured. The values measured vary widely. The very high values found in these samples cannot be explained by the mud additives used since none are known to contain any significant quantities of organic nitrogen. This leaves drill cuttings as the remaining possible source which may account for the variability noted. Nitrogen in most forms, except ammonia, is not regarded as directly harmful to receiving waters. However, if it is the nutrient which is limiting productivity, additions of nitrogen may stimulate eutrophication. In the case of ammonia, the toxicity is primarily associated with the unionized $\left(\mathrm{NH}_{3}\right)$ form rather than the ionized $\left(\mathrm{NH}_{4}{ }^{+}\right)$form. The equilibrium between these forms and thus the toxicity is controlled by $\mathrm{pH}$. The higher the $\mathrm{pH}$, the greater the proportion of ammonia present as $\mathrm{NH}_{3}$ and thus much greater toxicity is observed for a given quantity of ammonia nitrogen.

\section{Toxicological Characteristics}

The toxicological properties of industrial wastewaters are routinely assessed by standard acute lethality bioassay techniques employing fingerling 
rainbow trout as the test species. The results of such tests are commonly summarized as the $96 \mathrm{hr}$ LC50. The $96 \mathrm{hr}$ LC50 is expressed as a concentration by either mass per unit volume $(\mathrm{mg} / \mathrm{l})$ or by volume $\%$. The latter is used to express bioassay results for complex wastewaters which are tested by direct dilution from their natural $(100 \%)$ concentration. Thus, the lower an LC50 concentration, the greater the degree of toxicity apparent.

Bioassays were performed by Weir, et al. (1976) on several samples collected in this monitoring program. This data has been evaluated in Table 4 according to the mud type in use during the sample collection.

The findings of the toxicity testing indicate that surface hole mud is marginally more toxic than bottom hole mud and both are significantly more toxic than the intermediate hole waste mud samples tested. The final weighted mud sample, collected after drill stem testing is significantly more toxic than any other waste mud sample tested.

Some insight into these results can be gained by considering the likely sources of the observed toxicity in the mud additives used. For each mud type, the major additives used, their estimated concentration in the mud at the time of sampling (estimated from the mud logs) and their reported LC50 (Bryant, 1976) are provided.

For surface hole waste mud, it is apparent from the ratio of the LC50 of the mud additive to the estimated mud additive concentration in the sample, that bentonite is not likely a significant contributor to the observed toxicity. Likewise, the polymer does appear to be a contributor. The caustic would be a potential contributor but the observed toxicity was measured after neutralizing the samples to a $\mathrm{pH}>9$. In such circumstances the primary cause of caustic toxicity is removed. This leaves the potash as the likely cause of the toxicity observed. In fact, based on the estimated concentration used, one would be led to expect even lower values for the observed LC50. The failure to meet this expectation is likely due to the difficulty inherent in attempting to accurately estimate the actual concentrations of components in the mud. As well, the toxicity due to potash is most likely due to the potassium ion. The reported LC50 for potash alone was determined without the presence of significant quantities of other cations. In some cases of cation toxicity, it is found that other cations can reduce the toxicity of the test cation. This phenomenon is plausible for the case of potassium in drilling muds since many other cations are present in large quantity.

For the intermediate hole mud samples the limited toxicity observed is not apparently explained by the major additives, except for sample 5 . The toxicity could presumably be partially explained by synergistic action of several additives present in non-acutely toxic concentrations by themselves. Sample 5 implicates bentonite, barytes and lignosulphonate as possible contributors to toxicity. However, assessment of the contribution of bentonite and baryte to the observed toxicity is imprecise, at best, because of the heterogeneous nature of these materials. The lignosulphate contribution is likely more significant in any case. 
TABLE 4. Toxicity of Waste Drilling Muds

\begin{tabular}{|c|c|c|c|c|c|c|c|}
\hline Sample & $\begin{array}{l}\text { Mud } \\
\text { Description }\end{array}$ & $\begin{array}{l}\text { Mud } \\
\text { Additivies } \\
\end{array}$ & $\begin{array}{c}\text { Normal use } \\
\text { range, mg/l } \\
\text { (After Bryant, } \\
1976 \text { ) } \\
\end{array}$ & $\begin{array}{c}\text { Estimated } \\
\text { concentration } \\
\text { in sample } \\
\mathrm{mg} / l, \mathrm{E} \\
\end{array}$ & $\begin{array}{c}\text { Reported LCS0 } \\
\text { of Additive, } \\
\text { L, (After } \\
\text { Bryant, 1976) } \\
\end{array}$ & $\begin{array}{c}\text { Ratio } L / E \\
\%\end{array}$ & $\begin{array}{c}\text { Reported Sample } \\
\text { LC50 (After } \\
\text { Weir et al, } \\
1976 \text { ) } \\
\end{array}$ \\
\hline 1 & $\begin{array}{l}\text { Surface } \\
\text { hole mud }\end{array}$ & $\begin{array}{l}\text { bentonite } \\
\text { polymer } \\
\text { caustic } \\
\text { potash } \\
\end{array}$ & $\begin{array}{c}15,000-107,000 \\
1,500-4,300 \\
730-5,800 \\
29,000-58,000\end{array}$ & $\begin{array}{r}36,000 \\
1,500 \\
750 \\
30,000 \\
\end{array}$ & $\begin{array}{r}>50,000 \\
1,900 \\
105 \\
2,100\end{array}$ & $\begin{array}{c}139 \% \\
127 \% \\
\text { neutralized } \\
7 \%\end{array}$ & $17 \%$ \\
\hline 2 & $\begin{array}{l}\text { Surface } \\
\text { hole mud }\end{array}$ & $\begin{array}{l}\text { bentonite } \\
\text { polymer } \\
\text { caustic } \\
\text { potash } \\
\end{array}$ & $\begin{array}{c}15,000-107,000 \\
1,500-4,300 \\
730-5,800 \\
29,000-58,000 \\
\end{array}$ & $\begin{array}{r}24,000 \\
1,000 \\
500 \\
20,000 \\
\end{array}$ & $\begin{array}{r}>50,000 \\
1,900 \\
105 \\
2,100 \\
\end{array}$ & $\begin{array}{c}208 \% \\
190 \% \\
\text { neutralized } \\
11 \% \\
\end{array}$ & $22 \%$ \\
\hline 3 & $\begin{array}{l}\text { Intermediate } \\
\text { hole mud }\end{array}$ & $\begin{array}{l}\text { bentonite } \\
\text { polymer } \\
\text { caustic } \\
\text { barytes } \\
\text { lignosulphonate }\end{array}$ & $\begin{array}{c}15,000-107,000 \\
1,500-4,300 \\
730-5,800 \\
90,000-2,000,000 \\
2,900-29,000\end{array}$ & $\begin{array}{r}48,000 \\
1,500 \\
750 \\
30,000 \\
750 \\
\end{array}$ & $\begin{array}{r}>50,000 \\
1,900 \\
105 \\
>100,000 \\
3,000 \\
\end{array}$ & $\begin{array}{c}104 \% \\
127 \% \\
\text { neutralized } \\
333 \% \\
400 \% \\
\end{array}$ & $\begin{array}{c}\text { Not calculable } \\
\text { estimated to be } \\
50-60 \%\end{array}$ \\
\hline 4 & $\begin{array}{l}\text { Intermediate } \\
\text { hole mud }\end{array}$ & $\begin{array}{l}\text { bentonite } \\
\text { polymer } \\
\text { caustic } \\
\text { barytes } \\
\text { lignosulphonate }\end{array}$ & $\begin{array}{c}15,000-107,000 \\
1,500-4,300 \\
730-5,800 \\
90,000-2,000,000 \\
2,900-29,000\end{array}$ & $\begin{array}{r}48,000 \\
1,500 \\
750 \\
60,000 \\
2,600\end{array}$ & $\begin{array}{r}>50,000 \\
1,900 \\
105 \\
>100,000 \\
3,000\end{array}$ & $\begin{array}{c}104 \% \\
127 \% \\
\text { neutralized } \\
167 \% \\
115 \%\end{array}$ & $43 \%$ \\
\hline
\end{tabular}




\begin{tabular}{|c|c|c|c|c|c|c|c|}
\hline 5 & $\begin{array}{l}\text { Intermediate } \\
\text { hole mud }\end{array}$ & $\begin{array}{l}\text { bentonite } \\
\text { polymer } \\
\text { caustic } \\
\text { barytes } \\
\text { lignosulphonate }\end{array}$ & $\begin{array}{c}15,000-107,000 \\
1,500-4,300 \\
730-5,800 \\
90,000-2,000,000 \\
2,900-29,000 \\
\end{array}$ & $\begin{array}{r}60,000 \\
750 \\
3,000 \\
400,000 \\
4,000 \\
\end{array}$ & $\begin{array}{r}>50,000 \\
1,900 \\
105 \\
>100,000 \\
3,000 \\
\end{array}$ & $\begin{array}{c}>83 \% \\
253 \% \\
\text { neutralized } \\
>25 \% \\
75 \% \\
\end{array}$ & $59 \%$ \\
\hline 6 & $\begin{array}{l}\text { Bottom hole } \\
\text { weighted mud }\end{array}$ & $\begin{array}{l}\text { bentonite } \\
\text { caustic } \\
\text { barytes } \\
\text { lignosulphonate } \\
\text { sodium acid } \\
\text { phrophosphate }\end{array}$ & $\begin{array}{c}15,000-107,000 \\
730-5,800 \\
90,000-2,000,000 \\
2,900-29,000 \\
280-1,500\end{array}$ & $\begin{array}{r}69,000 \\
2,500 \\
650,000 \\
10,000 \\
250\end{array}$ & $\begin{array}{r}>50,000 \\
105 \\
>100,000 \\
3,000 \\
1,700\end{array}$ & $\begin{array}{c}>72 \% \\
\text { neutralized } \\
>15 \% \\
30 \% \\
680 \%\end{array}$ & $26 \%$ \\
\hline 7 & $\begin{array}{l}\text { Bottom hole } \\
\text { weighted mud }\end{array}$ & $\begin{array}{l}\text { bentonite } \\
\text { caustic } \\
\text { barytes } \\
\text { lignosulphonate } \\
\text { sodium acid } \\
\text { phyrophosphate }\end{array}$ & $\begin{array}{c}15,000-107,000 \\
730-5,800 \\
90,000-2,000,000 \\
2,900-29,000 \\
280-1,500\end{array}$ & $\begin{array}{r}66,000 \\
2,500 \\
1,000,000 \\
15,000 \\
200\end{array}$ & $\begin{array}{r}>50,000 \\
105 \\
>100,000 \\
3,000 \\
1,700\end{array}$ & $\begin{array}{c}>76 \% \\
\text { neutralized } \\
>10 \% \\
20 \% \\
850 \%\end{array}$ & $\begin{array}{c}\text { Not calculable } \\
\text { estimated to be } \\
15-20 \%\end{array}$ \\
\hline 8 & $\begin{array}{l}\text { Bottom hole } \\
\text { weighted mud } \\
\text { (drill stem } \\
\text { test) }\end{array}$ & $\begin{array}{l}\text { bentonite } \\
\text { caustic } \\
\text { barytes } \\
\text { lignosulphonate } \\
\text { sodium acid } \\
\text { pyrophosphate }\end{array}$ & $\begin{array}{c}15,000-107,000 \\
730-5,800 \\
90,000-2,000,000 \\
2,900-29,000 \\
280-1,500\end{array}$ & $\begin{array}{r}75,000 \\
4,500 \\
1,500,000 \\
30,000 \\
750\end{array}$ & $\begin{array}{r}>50,000 \\
105 \\
>100,000 \\
3,000 \\
1,700\end{array}$ & $\begin{array}{c}>67 \% \\
\text { neutralized } \\
>\quad 7 \% \\
10 \% \\
227 \%\end{array}$ & $3.3 \%$ \\
\hline
\end{tabular}


Organic nitrogen compounds will generally be converted to ammonia during microbial degradation before further oxidation (if ronditions are aerobic) to nitrites and nitrates. Therefore, the discharge of targe quantities of organic nitrogen could conceivably be harmful to receiving waters under unfortunate conditions of low dilution and dissolved oxygen concentration and high $\mathrm{pH}$ and microbial activity.

The petroleum ether extractible test is a liquid - liquid extraction procedure aimed at removing hydrophobic ether soluble organic compounds from a sample. The test is aimed at so-called "oils and greases" but will clearly extract any material which partitions from water into petroleum ether. Since the analysis is based on a quantitative determination of the residue extracted in the ether, care must be taken to avoid the carryover of inorganic solids and water with the ether. Because drilling muds form very stable emulsions with organic solvents, the analysis can be very difficult. These difficulties likely contribute to some of the variability seen in values reported for drilling fluids.

There is no strong trend apparent in the concentration of ether extractibles during the drilling program. The lack of a trend likely occurs because the ether extractibles are not intentionally added to the drilling fluid but they are contributed from leaking lubricating oils or from formation hydrocarbons.

Ether extractibles are undesirable in waste discharges, largely because of their tendency to float in receiving waters and because of the hazard they pose to waterfowl. Although the ether extractibles concentrations in waste mud samples appear undesirably high, they are likely present as emulsified oils, since discernible oil films could not be seen when waste fluids were diluted with seawater.

The chemical oxygen demand (COD) represents a measure of the degree to which sample constituents may be oxidized by a chemical oxidizing agent, potassium dichromate. It is generally used on organic wastes to estimate oxidizable organic content. However, if appreciably reduced inorganic matter is present, the organic matter is not distinguished by the test. The relatively high values of total organic carbon and total kjeldahl nitrogen will account for a significant portion of the measured COD since $1 \mathrm{mg} / l$ of reduced organic carbon or organic nitrogen could account for up to $5.3 \mathrm{mg} / \mathrm{l}$ or $4.6 \mathrm{mg} / \mathrm{l}$ of COD, respectively.

A correlation analysis for 10 mud samples which were concurrently analyzed for COD, TOC and TKN indicated a correlation coefficient of 0.98 for COD:TOC. This value is significant at the $99 \%$ confidence level for normally distributed variables. The correlation coefficient for COD:TKN was only 0.16 which indicates that these variables are likely not correlated for waste drilling mud samples.

Thus, the conclusions regarding the significance of COD in waste drilling fluids are largely the same as specified for TOC with the added confirmation that the organic matter present is susceptible to chemical oxidation.

The toxicity attributable to the bottom hole weighted mud samples is best explained by the larger contribution from lignosulphonate and barytes. As for the intermediate hole samples, the toxicity observed is likely more distinctly 
influenced by the lignosulphonate, with the baryte being a lesser factor. The one sample collected after drill stem testing exhibits even higher toxicity, which is not adequately explained by the known additives. It is presumed that the additional toxicity is due to traces of hydrocarbon resultant from the drill stem test.

\section{CONCLUSION}

Hydrocarbon exploratory drilling operations use water for a variety of purposes and consequently generate liquid wastes. Wastewaters are derived primarily from the mud treatment reject streams, waste mud and rig washwaters. The quantity of wastewater generated by exploratory drilling operation is generally not well documented. However, monitoring estimates during this study combined with earlier estimates of wastewater production for landbased operations indicate that operational control can result in significant reductions in the volume of liquid wastes to be discharged.

The chemical characteristics of drilling waste fluids determined in this study indicate a high degree of variability. This is likely due in part to the stated difficulty of accurately sampling and subsequently taking aliquots of waste samples for analysis. The characteristics and concentrations of the various parameters measured in this study indicate that these waste fluids could cause water pollution problems in specific circumstances. Unfortunately, conventional and advanced wastewater treatment technology is not applicable, in general, to these wastewaters. In particular, most technology which might be considered for these wastewaters would involve the creation of a sludge which would result in a renewed disposal problem. However, many of the characteristics identified are apparently degradable or are already present in significant quantity in saline water. For these characteristics, environmental problems should be minimized by undertaking close operational control to minimize the quantity of waste which requires discharge. Some of the characteristics, particularly chromium and ether extractibles are cause for greater concern. The ether extractibles normally represent hydrocarbons and the concentrations measured would indicate that undesirable levels of hydrocarbons were being discharged. On the other hand, there were no apparent signs of hydrocarbon in the diluted wastewater. However, the parameter warrants continued concern particularly if multiple discharges to a given receiving water are contemplated. Chromium, as a toxic metal contaminant, is undesirable in wastewaters, even at low concentrations. There must be special concern for toxic metals because they cannot be degraded in the receiving water and are generally only removed from activity in the aquatic ecosystem by incorporation and gradual burial in the sediment. Because specific chromium removal from drilling wastewaters would be very difficult, the best option would appear to be the reduction or elimination of chromium usage in drilling mud formulation wherever containment of drilling waste fluids is not feasible.

Evaluation of the acute toxicity of wastewaters from the exploratory drilling operations suggests that surface hole and bottom hole muds are generally 
more toxic than intermediate hole mud. The surface hole mud acute toxicity is apparently due to the use of potash in mud formulation. The toxicity associated with potash is most likely due to potassium ion and would not likely pose toxicity problems in saline receiving waters. The bottom hole mud toxicity is attributed to lignosulphonates and perhaps barytes. This toxicity is of greater concern and warrants better understanding to determine if the toxicants are persistent in receiving waters. The one sample of bottom hole mud was particularly toxic and further investigation of the causes of the observed toxicity is required.

It is apparent that the potential for water pollution problems exists for offshore drilling wastewater disposal. However, careful management to minimize the quantities of waste for disposal combined with judicious selection of drilling mud additives to avoid noxious components can be used to substantially reduce and manage the potential water pollution problems.

\section{ACKNOWLEDGEMENTS}

The author wishes to acknowledge the Arctic Petroleum Operators Association, Fisheries and Environment Canada, and Indian and Northern Affairs for supporting the program of studies which provide the data base for this paper. As well, the author acknowledges Mr. Wayne Bryant, District Manager, NWT District Office, Environmental Protection Service, Fisheries and Environment Canada for his contribution in initiating the program of studies into the water pollution problems associated with hydrocarbon exploration in the north.

\section{REFERENCES}

APHA. 1971. Standard methods for the examination of water and wastewaters. 13th ed. APHA-WPCF-AWWA. Washington.

BELL, J.B. 1974. Microbial analyses on drilling mud sample. Environment Canada Memorandum. In: Siferd, C.A.. 1976. Drilling Fluid Waste Characteristics from Drilling Operations in the Canadian North, Vol. 5. Industry/Government Working Group in Disposal of Waste Fluids from Petroleum Exploratory Drilling in the Canadian North. Environment Canada.

BRYANT, W. J., GOLDBURN, J. and HRUDEY, S. E. 1974. Water pollution aspects from waste drilling mud disposal. Proceedings 1974 Offshore Technology Conference, OTC 2044. Houston. pp. 95-102.

BRYANT, w. J. 1976. Editor: Summary Report, Vol. 1, Industry/Government Working Group in Disposal of Waste Fluids from Petroleum Exploratory Drilling in the Canadian North. Environment Canada.

BRYANT, W. J. and HRUDEY, S. E. 1976. Water pollution characteristics of drilling wastes from land based exploratory northern drilling operations, Vol. 3. Industry/Government Working Group in Disposal of Waste Fluids from Petroleum Exploratory Drilling in the Canadian North. Environment Canada.

CARBRERA, J. 1968. Survival of the oyster Crassostrea virginica (Gmelin) in the laboratory under the effect of oil drilling fluids spilled in the Laguna de Tamiahua, Mexico. Instituto de Biologica, Universidad Nacional Autonoma de Mexico. pp. 197-213.

ColliNS, G. 1971. Oil and gas wells - potential polluters of the environment. Journal of Water Pollution Control Federation. 43: 2382-2393.

DAUGHERTY, F. M. 1951. Effects of some chemicals used in oil well drilling on marine animals. Sewage and Industrial Wastes. 23: 1282-1287.

FALK, M. R. and LAWRENCE, M. J. 1973. Acute toxicity of petrochemical drilling fluid components and wastes to fish. Environment Canada, Fisheries and Marine Service. Report \#CEN T-73-1.

HRUDEY, S. E. and McMULLEN, J. D. 1976. Monitoring of two exploratory drilling sites in the shallow regions of Mackenzie Bay. Vol. 4. Industry/Government Working Group in Disposal of Waste Fluids from Petroleum Exploratory Drilling in the Canadian North. Environment Canada. 
HRUDEY, S. E., MICHALCHUK, J. and McMULLEN, J. D. 1976. A preliminary assessment of water pollution from abandoned oil and gas drilling sumps in the N.W.T. Vol. 2. Industry/Government Working Group in Disposal of Waste Fluids from Petroleum Exploratory Drilling in the Canadian North. Environment Canada.

LAND, B. 1974. The toxicity of drilling fluid components to aquatic biological systems. Environment Canada, Fisheries and Marine Service. Report \#CENT-73-1.

N.A.S. 1973. Water quality criteria - 1972. U.S. Environmental Protection Agency. Report \#EPA-R3-73-033.

STROSHER, M., KOSMAK, D. and BOGNER, J. 1974. Drilling mud and sump fluid analyses. An investigation of the reliability and confidence intervals of standard water quality analysis methods as they apply to drilling fluids. In: Bryant, W. J. and Hrudey, S.E., 1976. Water pollution characteristics of drilling wastes from land based exploratory drilling operations. Vol. 3. Industry/Government Working Group in Disposal of Waste Fluids from Petroleum Exploratory Drilling in the Canadian North. Environment Canada.

STROSHER, M. and BOGNER, J. 1975. Oil and grease analysis of drilling muds. In: Bryant, W. J. and Hrudey, S. E., 1976. Water pollution characteristics of drilling wastes from land based exploratory drilling operations. Vol. 3. Industry/Government Working Group in Disposal of Waste Fluids from Petroleum Exploratory Drilling in the Canadian North. Environment Canada.

WEIR, R.H., LAKE, W. H. and THACKERAY, B. T. 1976. Acute toxicity of discharged drilling muds from Immerk B-48, Beaufort Sea, to rainbow trout, Salmo gairdneri.Vol. 6. Industry/Government Working Group in Disposal of Waste Fluids from Petroleum Exploratory Drilling in the Canadian North. Environment Canada.

WRIGHT, T. R. 1977. (Ed.) Guide to drilling, workover and completion fluids. World Oil. vol. 184, (1), pp. 43-82. 